\title{
DEVELOPING MATERIALS FOR ESP (ENGLISH FOR SPECIFIC PURPOSES) CLASS
}

\author{
Umi Trisyanti*
}

\begin{abstract}
Abstrak
Some EFL teachers spend a great deal of time searching for textbooks appropriate to their learner's needs. But these teachers usually discover that the chosen textbook does not contain exactly what their students require. In order to ensure that the language and content covered in the materials are suitable to the learners' need and that the students are properly prepared for the real life situations of the target language, teachers are often required to write their own instructional materials from authentic sources.

This paper presents a course outline to develop a material for ESP class that can be used by TEFL teachers with an ESP audience. The texts used for the materials development are taken from authentic sources.
\end{abstract}

Key words: EFL, authentic sources, ESP class.

Material development is one of the important factors that determine the success of language teaching-learning process. Materials are a key component in language programs. Materials, whether commercially developed or teacherproduced, are an important element within the curriculum, and are often the most tangible and visible aspect of it. They give guidance to teachers on both the intensity of coverage and the amount of attention demanded by a particular content or pedagogical task. Some materials are designed to be used by inexperienced or poorly trained teachers; materials may serve as a form of teacher training. They provide ideas on how to plan and teach lesson as well as formats that teachers can use. The best materials, if they are used in the ways intended by their author, can be a useful professional development tool. Any of the materials that occur today may take the form of printed materials such as books, worksheets, workbooks; nonprint materials such as videos, computer-based materials; materials that comprise both print and nonprint sources such as selfaccess materials and materials from internet.

\footnotetext{
* Dosen pada Jurusan MKU FMIPA ITS.

jsh Jurnal Sosial Humaniora, Vo. 2, No. 1, Juni 2009
} 
Cunningsworth (1995:7) summarizes the role of materials (particularly course books) in language teaching as:

- a resource for presentation materials (spoken and written).

- a source of activities for learner practice and communicative interaction.

- a reference source for learners on grammar, vocabulary, pronunciation, and so on.

- a source of stimulation and ideas for classroom activities.

- a syllabus (where they reflect learning objectives that have already been determined.

- a support for less experienced teachers who have yet to gain in confidence.

A variety of published teaching materials that is aimed at specific levels for specific purposes and cover a full range of skills are available now. Some EFL teachers spend a great deal of time searching for textbooks appropriate to their learner needs. Teachers usually discover that the chosen textbook doesn't contain exactly what their students need to learn. In order that the content covered in the materials are suitable to the learner's need and the students are properly prepared for the real life situation of the target language, teachers are often required to write their own instructional materials.

Some of the materials focus on the study of English for specific purposes. Students in specific fields need to focus their attention on the kind of language used within their particular field. These materials are geared specifically toward people working in different service industry occupations such as hotel employees, restaurant chefs, factory workers and secretaries as well as toward students in academic.

The purpose of this paper is to provide ESL instructors as ESP class designer a model of material for ESP class. This paper begins with a discussion of the origin of ESP, some key notions about ESP, absolute and variable characteristics of ESP, types of ESP and characteristics of ESP courses and materials development for ESP. 


\section{The Origin of ESP}

ESP is an exciting movement in English language education that is opening up rich opportunities for English teachers and researchers in new professional domains. The ESP that is primarily taught consists of spoken and written discourse in academic and workplace settings, which is unfamiliar to learners and thus required special training. Specific-purpose English includes not only knowledge of a specific part of the English language but also competency in the skills required to use this language, as well as sufficient understanding of the contexts within which it is situated. In contrast to students learning English for general purposes, the ESP students are usually studying English in order to carry out a particular role, such as foreign students to become flight attendant, mechanic, or doctor.

Hutchinson and Waters (1997) state three reasons common to the emergence of ESP: the demands of a Brave New World, a revolution in linguistics, and focus on the learner.

For the demands of a Brave New World, they note that two key historical periods breathed life into ESP. First, the end of the Second World War brought with it an "... age of enormous and unprecedented expansion in scientific, technical and economic activity on an international scale for various reasons, most notably the economic power of the United States in the post war world, the role (of international language) fell to English" Hutchinson and Waters (1997: 6). Second, the Oil Crisis of the early 1970s resulted in Western money and knowledge flowing into the oil rich countries. The language of this knowledge was English. It now become subject to the wishes, needs and demands of people other than language teachers.

The second key reason cited as having a tremendous impact on the emergence of ESP was a revolution in linguistics. Hutchinson and Waters (1997) point out that one significant discovery was in the ways that spoken and written English vary. In other words, given the particular context in which English is used, the variant of English will change. If language in different situations varies, 
then tailoring language instruction to meet the needs of learners in specific context is also possible.

The final reason Hutchinson and Waters (1997) cite as having influenced the emergence of ESP has less to do with linguistics and psychology. Rather than simply focus on the method of language delivery, more attention were given to the ways in which learners acquired language and the differences in the ways language was acquired. Learners were seen to employ different learning strategies, use different skills, enter with different learning schemata, and be motivated by different needs and interests. Therefore, focus on the learners' needs became equally paramount as the methods that employed to disseminate linguistic knowledge. Designing specific courses to better meet these individual needs was a natural extension of material designer's problem. To this day, the catchword in ESL circles is learning centered.

\section{Key Notions About ESP}

In this discussion, three key notions will be discussed. They are as follows: a) the distinction between the absolute and variable characteristics of ESP, b) types of ESP, and c) characteristics of ESP courses.

\section{Absolute and Variable Characteristics of ESP}

Dudley- Evans and St. John (1998) define ESP by identifying its absolute and variable characteristics.

1. Absolute Characteristics: ESP is defined as meet specific needs of the learner; make use of the underlying methodology and activities of the discipline it serves; is centered on the language (grammar, lexis, register), skills, discourse and genres appropriate to these activities

2. Variable Characteristics: ESP may be related to or designed for specific disciplines; may be used in specific teaching situations, a different methodology from that of general English; is likely to be designed for adult learners, either at a tertiary level institution or in a 
professional work situation. It could, however, be for learners at secondary school level; is generally designed for intermediate or advanced students; most ESP courses assume some basic knowledge of the language system, but it can be used with beginners.

Types of ESP

Carter (1983) identifies three types of ESP: English as a restricted language, English for academic and occupational purposes, and English with specific topics. The language that is used by air traffic controllers and waiters is example of English as a restricted language. The second type of ESP identified by Carter (1993) is English for Academic and Occupational Purposes. In the "tree of ELT" from Hutchinson \&Waters (1987), ESP is broken down into three branches: English for Science and Technology (EST), English for Business and Economic (EBE), and English for Social Studies (ESS). Each of these subject areas is further divided into two branches: English for Academic Purposes (EAP) and English for occupational Purposes (EOP). An example of EOP for the EST branch is English for Technician, whereas the example of EAP for the EST branch is English for Medical studies. The third type of ESP is English with specific topics. Carter (1983) notes this type of ESP is uniquely concerned with anticipated future English needs, for example, scientists requiring English for postgraduate reading studies, attending conferences or working in foreign institutions. It is an integral component of ESP courses or programs which focus on situational language. This situational language has been determined based on the interpretation of results from needs analysis of authentic language used in target workplace settings.

\section{Characteristics of ESP}

Authentic materials, purpose-related orientation and self direction are three features common to ESP courses. If we revisit Dudley-Evans (1997) claim that ESP should be offered at an intermediate or advanced level, use of authentic learning material is entirely feasible. Closer examination of ESP materials will follow, suffice it to say at this juncture that use of authentic content materials, modified or unmodified in form, are indeed a feature of ESP, particularly in self- 
directed study and research tasks. Purpose-related orientation refers to the simulation of communicative tasks required of the target setting. Finally, selfdirection is characteristics of ESP courses in that the"...point of including selfdirection... is that ESP is concerned with turning learners into users" Carter (1983: 134). In order for self-direction to occur, the learners must have a certain degree of freedom to decide when, what, and how they will study.

\section{Materials Development for ESP}

Do ESP textbooks really exist? This is central question Jones (1990) addressed. One of the core dilemmas he presents is that "ESP teachers find themselves in a situation where they are expected to produce a course that exactly matches the needs of a group of learners, but are expected to do so with no, or very limited, preparation time" (Jones, 1990:91) In the real world, many ESP materials developers are not provided with ample time for needs analysis, materials research and materials development.

Teaching materials for ESP tend to be viewed as distinct and separate from general materials. This may be because of the emphasis on content and the unfamiliarity of the content to many teachers. There are also differences in the roles of teachers and learners and in the design of the materials. For these reasons we need some additional considerations in mind when selecting ESP materials.

Dudley-Evans and St. John (1998) suggest that for teachers of ESP courses, materials serve the following functions: as a source of language, as a learning support, as motivation and stimulation, and as a reference. ESP materials may therefore seek to provide exposure to the specialized genres and registers of ESP, to support learning through stimulating cognitive processes and providing a structure and progression for learners to follow, to motivate learners through providing achievable challenges and interesting content, and to provide a resource for self study outside of the classroom. 
To those who are uninitiated to ESP, the approach and materials can seem unfamiliar and inaccessible. However, this is a misleading impression probably created by the specialized and often technical nature of the subject content in ESP books. The range of ESP books on the market is large and covers many disciplines and occupations. Although the content of ESP books may look very different from that of general books, and the skills being developed may be different from those in general book, the guidelines for the evaluation of general materials also apply to ESP materials.

Cunningsworth (1995) states that the guidelines of selecting ESP materials include: analysis, interpretation, evaluation and selection. Analysis is more or less neutral, seeking information in a range of categories, and provides the necessary data for the next step of the process. This is the interpretation of the data obtained. Here a good deal of professional judgment and experience comes into play as the implications of the analysis are worked out. The third step is evaluation. It involves value judgments on the part of those involved. Such value judgments will inevitably be subjective to some extent and will reflect the views and priorities of those making them. They will tend to be based on a number of factors such as learner and teachers expectations, methodology, the perceived needs of the learners, syllabus requirements, and personal preferences. Selection is the last step of this process and involves matching the features identified during the previous steps against the requirements of a particular learning/teaching situation.

We should check that ESP materials meet learners' needs and that the language taught matches the language that the students use. The materials should take into account learner expectations and should have a clear role in the teachinglearning process. If meeting learners' needs was concerned, ESP materials have been in advance of general materials. They have been developed specially for students who were perceived to have specific needs which could not be met fully by general materials. These needs were originally seen mainly in terms of subject content, for example doctors need the language of medicine, engineers need the language of engineering, pilots need the language of aviation, etc. Clearly, it is 
beyond the bounds of possibility for published materials to cope specifically with distinctions which seem so fine to us, but which are fundamental to specialists in their own fields. To some extent, teachers on ESP class can supply the published materials available by producing their own materials based on specialized texts. Some teachers also adopt materials from subject areas such as science, engineering, and medicine and at the same time focusing on the skill, strategies and abilities that learners need in order to operate effectively in their disciplines in English.

Designing ESP materials differ from general materials. ESP materials will generally assume a foundation of proficiency in general English, and from the start will focus on aspect of English specific to the subject area being covered. The balance of language skills being taught may be different from that found in general courses. Flexibility, is used in a particularly valuable asset in ESP materials, as there may be very special constrains operating in the leaningteaching situation. For example, in a business context learners may be extremely busy in their work and may also be subject to unexpected demands on their time, leading to sporadic attendance or an irregular study pattern. Materials that can accommodate this will be more effective than materials that cannot accommodate. A modular design, with each unit being as self contained as possible, allows learners to continue to study effectively even when several lessons have been missed. Materials which can be used for individual study whenever time is available will also be advantageous, allowing learners to cover the ground of any lessons missed and to work independently on material which is particularly relevant to their needs.

In this sub-topic, a model of material for a specific group of ESP learners will be discussed. In this section, a brief outline of the course as a whole, to show where the unit fits, and a map of the sample lesson and students activity of the sample lesson will be described.

\section{Course Outline}


Interest in the urban challenges raised by the growing debates on sustainable development and global environment change has increased rapidly in recent years. This ESP course on Urban Development Problems is then meant to respond to this growing interest in the role of cities in the sustainable development process. The syllabus design of this course is topic-based, covering a wide variety of global issues on urban development and the environment. The activities in the course is designed to incorporate the four language skills (Reading, Speaking, Listening, and Writing) as well as language use needed by learners to communicate effectively in various professional settings in the target language. The framework for the course book being proposed is presented as follows:

\section{Urban Development Problems}

Unit one: Urban Development and the Environment

Lesson 1: Urban Problems

Lesson 2: Cities and the Environment

Unit two: Urban growth and the Urban Environment

Lesson 3: Why Cities Grow

Lesson 4: City Size and Settlement Planning

Unit three: The Urban Climate and Air Pollution

Lesson 5: Urban Climate

Lesson 6: Air Pollution

Unit four: Fresh Water Resources and Water Pollution

Lesson 7: fresh Water Resources

Lesson 8: Water Pollution

Unit five: Toward the Sustainable City

Lesson 9: Ideal City

Lesson 10: Managing the Sustainable City

For this paper, lesson 1: Urban Problems is chosen as a sample unit. Lesson one is meant to be an introductory section describing some of the main urban development issues, which currently pre-occupy many policy makers such as those in the office of the environment. The following is the Map of Lesson One 


\section{Map of Lesson One}

\begin{tabular}{|c|c|}
\hline Activity & Task \\
\hline \multirow[t]{2}{*}{ 1. Pre- reading } & 1.1 Warm-up \\
\hline & 1.2 Prediction \\
\hline \multirow[t]{3}{*}{ 2. While-reading } & 2.1 Skimming \\
\hline & 2.2 Text diagramming \\
\hline & 2.3 Scanning \\
\hline \multirow[t]{2}{*}{ 3. Post reading } & 3.1 Text summary \\
\hline & 3.2 Reading comprehension \\
\hline 4. Language in focus & 4 Language use \\
\hline \multirow[t]{2}{*}{ 5. Meaning in context } & 5.1 Puzzling out the meaning of words \\
\hline & 5.2 Vocabulary reinforcement \\
\hline \multirow[t]{2}{*}{ 6. Discussion } & 6.1 Group discussion \\
\hline & 6.2 Class presentation \\
\hline \multirow[t]{2}{*}{ 7. Writing } & 7.1 Problem solution \\
\hline & 7.2 A letter of recommendation \\
\hline
\end{tabular}

\section{Students' Activity}

In this unit students will read a text about Urban Problems and this unit will give them practice in:

1. answering pre-reading questions,

2. predicting text, 
3. understanding the main ideas in a text,

4. understanding detailed information,

5. guessing unknown vocabulary,

6. raising awareness of language in use,

7. discussing issues on urban and environmental problems,

8. writing a letter of recommendation.

\section{Conclusion}

ESP courses are developed through a need assessment that identifies what the students need to do in English, the relevant content and their current level of English.

The main point iof this paper is that materials should match learner needs and wants, and principles of language learning. They should be developed in ways which provide flexibility of use as well as coherence of connection. The best way to achieve this is to consider both the target context of use and our principles and experience, and then to develop a flexible framework to guide the development of materials.

\section{References}

Carter, David. 1983. Some Propositions about ESP. The ESP journal, 2: 131-137.

Cunningsworth, Alan. 1995. Choosing your coursebook. Macmillan Publisher Limited.

Dudley-Evans, T., \& St John, M. 1998. Developments in ESP: A Multidisciplinary Approach. Cambridge: Cambridge University Press.

Hutchinson, T., \& Waters, A. 1987. English for Specific Purposes: A learningcentered Approach. Cambridge: Cambridge University Press.

Jones, A., \& Dudley-Evans, T. 1991. English for Specific Purposes: International in scope, specific in purpose. TESOL Quarterly, 25:297-314. 
Jones, G. 1990. English for Specific Purposes. Cambrigde: Cambridge University Press.

Nunan, David. 1991. Language Teaching Methodology. New York: Prentice Hall International. 